Marquette University

e-Publications@Marquette

$1-1-1980$

\title{
A Re-examination of the 'Death of Art' Interpretation of Hegel's Aesthetics
}

Curtis Carter

Marquette University, curtis.carter@marquette.edu

Published version. "A Re-examination of the 'Death of Art' Interpretation of Hegel's Aesthetics," in Art and Logic in Hegel's Philosophy. Eds. Warren E. Steinkraus and Kenneth I. Schmitz. Atlantic Highlands, NJ: Humanities Press, 1980: 83-100. Permalink. (C) 1980 Humanities Press Inc. 


\title{
$\mathrm{V}$ \\ A Re-examination of the 'Death of Art' Interpretation of Hegel's Aesthetics
}

by

\author{
CURTIS L. CARTER
}

There was a time in our very recent past when we were told that all-encompassing theories of art were unfruitful. But losing one's perspective in the rich field of particularity in art, or in a narrow analytical focus on art concepts, will no more produce significant understanding than will arid theories apart from experiencing the qualities of individual art works. It is possible to retain the insights of both approaches, into particular works with their distinctive qualities and into the analysis of art concepts, by not treating the two activities as ends in themselves. In the philosophy of art there is a need to take up 'once again the grand scheme that relates art to other aspects of human experience, and connects to a study of art concepts, insights derived from attending to particular works.

What better way to do this than to re-examine the grandest of the grand schemes for a philosophy of art? There is good reason to regard Hegel's philosophy of art as a means to overcome deficiencies found in the two approaches considered above. It relates art to other aspects of human experience, nature, culture, and to the world order. At the same time Hegel's philosophy of art emerges from his own extensive acquaintance with the arts. The possibility that his approach to art fulfills the need to relate the particular perceptions and analysis of concepts to each other in the wider scope of human experience is quite strong. There is no doubt that Hegel provides one of the richest accounts of art given by any philosopher. Yet, there exists a formidable obstacle to the appreciation of his aesthetics. The dominant trend has been to interpret Hegel's Lectures on Aesthetics and his other materials on art as signifying the "death of art," or the view that art as a significant human activity reaches its end with the dissolution of romantic art. Erich Heller's statement is representative: 
Both Hegel's Classical and Romantic art emerge from his metaphysics as sentenced to death by the very law of the Spirit. Classical art had to die because the Spirit could not abide by the perfect understanding it had reached with concrete reality; for it lies in the Spirit's true nature that in the end it should be rid of all sensuous encumbrance. . . Romantic art is the negation of the very idea of art . . . as the body of the Idea. ${ }^{1}$

The view is shared by Croce, Israel Knox, and others who have considered the question less carefully:

The German refused to evade the logical exigencies of his system and proclaimed the mortality, nay the very death, of art.... He passes in review the successive forms of art, shows the progressive steps of internal consumption and lays the whole in its grave, leaving philosophy to write its epitaph. ${ }^{2}$

By a process of sheer dialectical deduction Hegel infers the death of art; it is necessitated by the conceptual determinism of his metaphysical dialectical absolutism. ${ }^{3}$

Even those who have indicated their lack of support for the prevailing interpretation-Bosanquet, D'Hondt, Findlay, and Harries-have not offered an adequate examination of the inadequacy of the view that Hegel intends to signal the death of art. Bosanquet argues that Croce misunderstands Hegel's logic and mistranslates the term 'Auflösung' as 'death of art'; he thereby agrees with my position that Croce errs in attributing the death of art thesis to Hegel. ${ }^{4}$ And these words of professor D'Hondt affirm a similar conclusion: "Hegel a-t-il annoncé la mort de l'art? Impossible de lui imputer un tel crime. ... Il n'emploie jamais ces mots, la mort de l'art, et il lui arrive d'exprimer des opinions qui contredisent cette pensée funèbre."5 Professor Harries also agrees that Hegel should not be interpreted as proclaiming the death of art; but Harries does accept a weaker version of the death of art thesis when he claims that for Hegel art has lost its highest vocation and asserts that art is in a position to offer the modern world no more than a diversion. ${ }^{6}$ Finally, it is surely significant that so notable an interpreter of Hegel as Professor Findlay makes no mention of "the death of art" in his own account of Hegel's view of art. ${ }^{7}$

The paper will develop further the notion that the death of art interpretation is unwarranted by critically examining the arguments of Heller, Croce, and Knox, with reference to the Lectures on Aesthetics and 
Hegel's other writings on art. The analysis of crucial texts will result in support for the alternative thesis that Hegel did not intend the death of art and that he explicitly and implicitly provides for the continuation and development of art. He explicitly provides for the continuation of art through its participation in the more inclusive accounts of Absolute Spirit offered by religion and philosophy, which are the other two modes of Absolute Spirit. Additionally, Hegel's aesthetics implicitly liberates art from its past forms and from a narrow construing of content. Art is thus free to develop new forms in the light of future creative activity of individual artists acting in relation to the cultures of their times.

The very richness and complexity of Hegel's discussion of art, not to mention the relation of the material on art to the larger themes of Hegel's system, make hazardous any attempt to give a final reading of Hegel's view on the place and future of art. The same richness suggests a many-sided gem that cannot be examined sufficiently from a single perspective. My primary objective here is not to refute conclusively the death of art interpretation but to set forth the problem in a form that will generate further discussion and rethinking that will lead to clarification of an important aspect of Hegel's philosophy of art. The paper will develop the following points: (1) The claim that Hegel's metaphysical dialectical principle necessarily produces the death of art is shown to be based on a misapplication of the principle of the dialectic. (2) A review of the texts most likely to support the death of art thesis establishes sufficient qualifications in every case to support an alternative interpretation of the texts. (3) The death of art thesis misunderstands the dissolution in romantic art of subjective and sensuous elements and confuses changes in romantic art with the demise of all art.

\section{Misapplications of the Principles of Dialectic}

Characteristic of the death of art interpretation are applications of the principle of dialectic or development which are in one way or another hostile to the welfare of art. Dialectic can be applied to Hegel's view of art at two levels. It is applied to the relation between art, religion, and philosophy, which are the three modes of disclosing Abso- 
lute Spirit to man's consciousness. Art is understood to be Spirit's "sensuous manifestation." Religion and philosophy are more "ideal" and more inclusive representations which come closer to the true qualities of Spirit. ${ }^{8}$ (HA, 101-105) Dialectic also operates in reference to the states of the idea of art: symbolic, classical, and romantic.

Croce, Heller, and Knox base their argument for the death of art interpretation on a mechanical view of the role of dialectic. According to their interpretation, the death of art is a necessary logical consequence of the dialectical unfolding of Absolute Spirit. As the dialectic unfolds at this level we find that beauty in art is a synthesis of the sensuous and the rational, romantic art is a synthesis of symbolic and classical art, and philosophy is a synthesis of art and religion. ${ }^{9}$ Art's demise is projected on two levels. The appearance of philosophy as the most complete and definitive presentation of Absolute Spirit is understood to dispense with the need for art. Analogously, on another level the dialectic manifests itself in the symbolic, classical, and romantic forms of art. These successive forms are said to "pass in review" until art reaches its outer limits as a viable expression of Absolute Spirit, thus drawing to a close the life of art. ${ }^{10}$

\section{A. The dialectic applied to art, religion, and philosophy}

The first line of criticism of the death of art thesis can be made with respect to dialectical development in the progression from art to philosophy. It will be necessary to give a brief explanation of Hegel's view on this point to see where the death of art thesis has gone wrong. The thesis is problematic because it presumes that an advancement in the stages of dialectic evolution from art to philosophy results in the annihilation or uselessness of the previous stages. This view is in conflict with Hegel's explanation of the dialectic. Hegel describes the stages of the dialectic in his Preface to The Phenomenology of Mind as equally necessary moments of an organic unity that constitute the life of the whole. Hyppolite and other distinguished commentators on Hegel's system have proposed that the stages in Hegel's dialectic move to ever richer developments and "always reproduce within themselves the prior developments and give them new meaning." 11 I shall adopt this interpretation of Hegel's dialectic because it represents Hegel's general 
philosophical method and because it is in fact the method that he uses to discuss both the relations between art, religion, and philosophy and the various stages in the development of art.

Hegel does distinguish the points of view of the artist and the philosopher, and he clearly differentiates art from philosophy. The artist's task is to grasp reality and its forms through alert eyes and ears. Although reason acts to enable the artist to relate his perceptions to the idea of Absolute Spirit, the artist does not comprehend experience in propositions and representations (Sätze und Vorstellungen) as does the philosopher. Rather, the artist brings to consciousness the inner core of reason clothed in concrete forms and the individualities of real life. His representations are so infused with the stamp of emotional life that they make public a part of the artist's own spiritual personality. ${ }^{12}$ (HA, 281-82) Art is thereby capable only of presenting those aspects of the Absolute which can be expressed in sensuous form. By contrast, the point of view of philosophy is that of the whole, the absolute, God. Philosophy or thought is the mode of apprehension in which both subject and form are identical. Philosophy is thus the self-reflection of Absolute Spirit. ${ }^{13}$ (HA, 101, 105) The model that is suggested is incarnation - in philosophy we have the disclosing of God as he knows himself-and the point of view of philosophy thereby becomes the most inclusive account of being. ${ }^{14}$

There is no doubt then that Hegel assigns philosophy, understood in the above sense, a higher place than art as a manifestation of Absolute Spirit. (HA, 10-11) In the Phenomenology art is placed very high but not at the highest stage of the dialectical development. Hegel assigns philosophy a higher place than art in his Aesthetics too. Art ranks highest in neither form nor content, and Hegel's choice of philosophy as the more inclusive mode of Spirit suggests his preference. ${ }^{15}$ But none of these facts warrant the conclusion of Knox and the others that Hegel pronounces the death of art. Hegel's concept of philosophy incorporates art into its more comprehensive grasp of things. Both art and religion are united (vereinigt) in philosophy where their characteristics are related to the form and subjectivity of thought. Art is neither lost nor abandoned in the more comprehensive synthesis of philosophy, but continues to function as a vital part of the larger unity. The expression of the Absolute in relation to dialectic and philosophy would be incomplete without the continued participation of art as one of the ele- 
ments of the whole. ${ }^{16}$ There is no need to think of destruction of previous modes, art and religion, because it is characteristic of dialectic that the higher mode integrates the content of lower ones as aspects of a wider scope where the previous categories can exist without contradiction. ${ }^{17}$ At the same time, the significance of the previous categories is retained.

\section{B. The Dialectic in Symbolic, Classical, Romantic Forms of Art}

The manifestation of dialectic in symbolic, classical, and romantic art forms is another part of the argument for the death of art thesis. Knox states that romantic art is a consuming synthesis of the other two forms, and Heller describes the romantic form as the disintegration of art itself. Its demise is thus offered as evidence for the death of art thesis. A brief examination of Hegel's discussion of these forms is necessary to show that support for the death of art thesis is lacking here too.

Each of the forms is effective in some degree as a representation of Absolute Spirit. Symbolic art, the first, is closest to nature. The sensuous element in art and Absolute Spirit are brought into proximity at this level, but they are unable to achieve a unification of the sensuous form and spiritual content of art. ${ }^{18}$ (HA, 655) The earliest forms of symbolic art, being close to nature, exhibit the principle of the productive energy of generation. ${ }^{19}$ (HA, 641) Phallus and Lingam are examples of organic shapes used in symbolic art. They appear as pillars and columns constructed in the shapes of male and female sex organs. These can be seen in the early pre-architectural and architectural forms in the arts of Syria, India, and Egypt. The height of symbolic art comes in architectural structures such as the pyramids which in part abandon the shapes of nature for shapes that derive from the artistic powers of man's mind. The pyramids, unlike structures which merely satisfy the physical want of shelter, act as religious and political symbols. ${ }^{20}$ (HA, 653, 655) Despite its degree of success, symbolic art lacks both the form and the adequate grasp of Spirit as its content that is found in later developments in art.

Classical art advances the development. Its sculpture takes its preferred model from the human body. Unlike the other natural animal 
bodies whose bodily frames are animated by animal soul (Seele), the human form also has a quality of spirit (Geist). ${ }^{21}$ (HA, 714-15) Spirit is explained here as "being for itself of conscious and self-conscious existence," together with the emotions, ideas, and purposes of that existence. The universal qualities of the human form are ideally receptive to a unity of form and content by which Spirit enters into the sensuous form of the sculpture, analogous to the receptivity of the human body to Spirit. However the unity of classical art bypasses the genuinely subjective aspects of personal self-consciousness and is found to be unstable. $^{22}$ (HA, 716-18) The result is the dissolution of the objective unity of the classical form of art.

The emergence of romantic art introduces the last of Hegel's determinate forms of art. A careful understanding of Hegel's view of the romantic form of art is very important to the clarification of the death of art issue. Advocates of the death of art thesis emphasize two themes arising from romantic art. They assert that romantic art consumes the previous forms of art through the workings of dialectic and then point to the alleged disengagement of inner subjective aspects from outer sensuous form as the definitive evidence for the death of art. But I will show that the synthesis of the previous forms of art into romantic art and the changed relation of the subjective and sensuous elements that Hegel finds in romantic art do not entail the death of art. Croce and the others who interpret Hegel's aesthetics according to the death of art hypothesis fail to see that synthesis in romantic art includes the previously independent forms without destroying them. The changed relation of sensuous and subjective elements in romantic art, moreover, is not synonymous with art's demise.

\section{Synthesis in Romantic Art}

The romantic arts of painting, music, and poetry each provide some synthesis of the previous forms of art. Painting takes representations of environments from architecture and uses them as background settings for the human figure which it borrows from sculpture. (HA, 797f) Poetry then combines "essential qualities" of painting and music to embrace the most inclusive perspective of the arts. Hegel's remarks on dramatic poetry offer another example of the dialectic synthesis in a 
particular romantic art. There, the synthesis shows the "lesser arts - architecture, sculpture, painting, and music-appearing as vital parts in a theater presentation of dramatic poetry. ${ }^{23}$ (HA, $1181 \mathrm{f}$ and 1190) Shakespeare's "Hamlet" and Mozart's "Magic Flute," each in its own way, illustrates the synthesis by its use of the lesser arts in the total "poetry" of a dramatic performance.

According to the death of art thesis, we should expect the workings of dialectic to produce the destruction of the lesser and prior stages of art. But quite a different effect is seen. These representative samples of dialectic synthesis taken from Hegel's discussion of romantic arts show that the lesser arts, or principles derived from them, are retained and used in the context of a larger purpose. On the other hand, neither example suggests any use of these arts that would result in their cancellation apart from the synthesis. Nothing in the painter's use of principles borrowed from architecture and sculpture makes painting an adequate replacement of these two arts. And likewise the use of music in a drama does no violence to its status as music. The examination of dialectic in romantic art thus fails to support the death of art thesis; instead, it reinforces the previous point that dialectic incorporates rather than destroys earlier stages of its development.

\section{The Changed Relation of Sensuous Form and the Subjective in Romantic Art}

The development of romantic art signifies a shift of emphasis from the sensuous or visible form and its relation to Absolute Spirit to selfconscious subjectivity - the inner world of the ideal and of emotions, soul, and contemplation, of the subject. (HA, 792-96) Personal subjectivity and its involvement with Absolute Spirit are the main center of interest for this changed point of view. This shift has been understood by the advocates of the death of art thesis as an irrevocable split between two essential elements of art, resulting in art's permanent dissolution. However, an examination of Hegel's discussion of this point suggests that too great an emphasis has been placed on the alleged disengagement of sense and subjectivity. Hegel is partly to blame, for his language at times does appear to suggest such a reading. Yet careful attention to the full context of the discussion shows Hegel repeatedly 
reminding the reader of the continuing necessity for a vital relation between the sensuous and the subjective in art. (HA, 795)

Admittedly, there is less attention given by Hegel to the positive role of the sensuous element in romantic art. But the shift has a different purpose than to bring to an end the life of art. The shift is wrought in part to emphasize the differences between classical and romantic art. Hegel finds too little involvement of personal subjective life in classical art. By comparison, romantic art satisfies this lack. Hegel thus gives prominence to the subjective by de-emphasizing the visible. But this does not mean that romantic art can exist apart from its sensuous form. Romantic art is compelled to operate in the realms of the visible and the sensible (Sicbbaren und Sinnlichen) to communicate the developments of inner life. ${ }^{24}$ (HA, 795f)

The need to communicate the inner workings of imagination suggests another way of looking at the changed role of sensuous form in romantic art. In classical art the visible form acts as a symbol participating as fully as possible in the ontological meaning of Absolute Spirit. But the visible form in romantic art acts more as a sign,' communicating the artistic happenings of subjective life without being the main center of interest. (HA, 795f) The distinction between symbol and sign could be misleading here. It should not be understood to mean simply that the visible has no significance. Hegel is attempting to show that the significance of the visible is not due to its natural sensuous qualities but comes instead from the fact that imagination subjects the natural qualities to its own subjective purposes and thus transforms the qualities of a medium into art. ${ }^{25}$

\section{Discussion of Particular Texts}

Even those who agree with the first point, that the dialectic argument fails to support the death of art thesis, may puzzle over certain of Hegel's texts that are cited in support of the thesis. The following interpretation of three principal texts will suggest that they do not necessarily uphold the thesis. The texts are taken from representative major divisions of Hegel's Lectures on Aesthetics, one each corresponding to the general idea of a philosophy of art, to a particular form of art, and to a particular medium. The first concerns Hegel's justification for 
a philosophy of art and the limits and place of art relative to religion and philosophy; the second considers the nature and implications of the dissolution of the romantic form of art; and the third concerns the role of sensuous or external form in poetry. All three bear directly and critically on the acceptance or rejection of the death of art thesis.

\section{A. "Art is and remains for us, on the side of its bighest possibilities, a thing of the past." $(H A, 11)^{26}$}

The larger context of the quotation is the introduction to the Lectures on Aesthetics where Hegel justifies the need for a philosophy of art. Since the statement is a part of his rationale for writing a philosophy of art, it necessarily takes on a function of apology or justification. It shows in part why Hegel is doing philosophy rather than making paintings or poems. More importantly, the statement expresses the larger need for a form of thought to accommodate the deficiencies that he sees in the art of his own age and culture. The statement expresses Hegel's belief that the critical and reflective activities of his own age are not conducive to the creation of significant art; but it should not be taken as a definitive pronouncement on the future of art for all ages. Here I agree with Gray's point that the emphasis in the passage under consideration is on the "for us," and that art will "in the evolution of ages" continue to awaken man to self-knowledge and truth. ${ }^{\mathbf{2 7}}$

The immediate context of the quotation is a preliminary account of the reasons for making philosophy the supreme approach to Absolute Spirit. According to Hegel, art is one, but not the only, and not necessarily the most adequate expression of man's highest concerns. It is important for the argument of this paper to note that the limitations placed on art by Hegel are quite specific, rather than general or allinclusive ones. The limits are in terms of seeing art as the highest approach to the ultimate truths of the religious point of view of Hegel's time, or of Hegel's own Christian religious point of view. He finds art insufficient to bring the "true interests of our spiritual life to consciousness," and "no longer able to discover that satisfaction of spiritual wants, which previous epochs and nations have . . exclusively found in it," e.g., the good days of Greek art and the golden time of the later Middle Ages. ${ }^{28}$ (HA, 9-10) Though art, in Hegel's view, is not as adequate as religion or philosophy for satisfying man's 
spiritual wants, art nevertheless retains its place as a highly valued activity, both for Hegel and for the future. Here and elsewhere the limitations of art are stated in relative and qualified terms.

Finally, it is a part of a much larger aspect of Hegel interpretation to decide whether the forward progress of the dialectic is a process in time. ${ }^{29}$ In the Pbenomenology, the dialectic is, in part, in time, and the moments in the history of a particular civilization are the movements of the dialectic. Hegel wants to speak in such a way that what he says applies to such moments as when religion or art or philosophy is the dominant voice in a particular historical period, say ancient Greece or modern Germany. But he doesn't necessarily want his categories of art, religion, and philosophy to be tied to these particular phenomena in history. Hegel is also timelessly locating art relative to its place in the total assortment of human values rather than asserting that art is dead because still higher values rise above it, e.g., philosophy or absolute knowledge. (HA, 82-90)

Along the same lines, Hegel sees the dialectic manifesting itself in such particular stylistic moments as the classical style of ahcient Greece and the romantic style of nineteenth century Germany. But he does not restrict the symbolic, classical, and romantic modes of art to a determined progress of the dialectic in time. These modes are timeless, universal forms of art. They, and possibly others that have yet to emerge, are necessary to provide a view of art in all of its aspects and to show its relation to the whole, which is, for Hegel, the true.

B. "We find. . . as the termination of romantic art, the contingency of the exterior condition and internal life, and a falling asunder of the two aspects, by reason of which art commits an act of suicide. . .."30

The second text to be considered occurs in a discussion of the dissolution of romantic art. In this context, Hegel speaks of a "falling asunder" (Auseinanderfallen) of the sensuous and the subjective elements of romantic art, with the result that art allegedly dissolves itself in the process (selbst sich aufbebt). Dissolution is interpreted by advocates of the death of art thesis to mean the death or demise of art. And this interpretation has been a part of the basis for the support of the thesis. 
Osmaston's translation of the phrase, "Kunst selbst sich aufhebt," into the English, "Art commits an act of suicide," may have inadvertently served to perpetuate the death of art interpretation, especially among English readers of Hegel. However, insofar as I can determine, Hegel never actually uses the phrase, "the death of art." Osmaston's translation is suggestive only in its fanciful and misleading character. Hegel's text neither benefits from nor requires translation in a manner suggesting the suicide image. The translator ignores the fact that in aufheben he has one of Hegel's most enigmatic terms. One of the most important notions in all of Hegel, aufheben literally means to raise up something; however, as a philosophical notion it can mean "cancel," "dissolve," or "preserve," or all three at once! Hegel may have resorted to a certain amount of punstering to convey the essence of his dialectical method of interpreting the sensuous and the subjective elements of art. Nevertheless aufbeben with its multiple connotations assembles the several aspects of the dialectic process with admirable verbal economy.

I would like to propose an alternative to Osmaston's translation of aufheben based on the idea of dissolve. 'Dissolve' includes both the elements of "cancel" and "preserve," and it expresses the appropriate meanings of both Auseinanderfallen and selbst sich aufhebt which are the principal terms in the text that is under consideration here. In this case, to dissolve is not the same as to destroy. The dissolution in romantic art is more akin to the modern cinematic principles of dissolve. In a film, to dissolve is to fade out one shot or scene while simultaneously fading in the next, overlapping the two during the process. ${ }^{31}$ The camera focuses on an object that dissolves in degrees into a near blur, only to re-emerge as a distinctly new object that retains some of the qualities of the object it has replaced.

The analogous process of "dissolve" in romantic art takes place on the level of the relation of visible sensuous form to the inner subjective workings of imagination. Natural qualities of sensuous form "dissolve" into a new image as they are transformed by the qualities and activities of subjective imagination. In the new image, the natural qualities are retained but are "in the service of" the artist's spirit, feelings, and ideas.

The results of my application of the principle of dissolve are visible in a comparison of a Greek "Bust of Zeus" with Rembrandt's "Portrait of a Young Man, 1662."32 The bust acts as an ideal vehicle for reveal- 
ing Absolute Spirit to man's consciousness, according to Hegel's category of classical art. Its universal qualities of sensuous form are abstracted from the human form, but they retain their independence from personal subjectivity and also from complete unity with Absolute Spirit. By comparison, Rembrandt's portrait shows the dissolve of the natural sensuous qualities of color and line into a new image. They reveal the human qualities of a sensitive, fragile personality who is enigmatic in his very lack of a distinct focus. The viewer is aware of the painting's rich sensuous qualities primarily through their disclosure of the particular qualities of the subject's inner life.

A similar effect occurs in two different pictorial scenes. Monet's "Charing Cross Bridge, 1903" shows sensuous form in the relative absence of its domination by subjective purposes. Monet arranges color and light in a manner of scientific objectivity and shows the surfaces of both the painting and its representation of the scene primarily for their sensory values. Consider also Doré's "Loch Lomond, 1875." Compared to Monet's "Charing Cross Bridge," "Loch Lomond" displays a strong sense of the artist's subjective vision of the nature scene. Colors and lines are no less present in the Doré painting, but they do not project their sensory values independently of displaying the artist's vision of an aura of mystery and legend.

The differences in both sets of examples are between art works that show the sensuous qualities retaining a high degree of independence and exhibiting forms that are simply extensions of the natural qualities, and works where the artist's subjective spirit dissolves the sensuous in a more personal representation. The sensuous element is not lost or abandoned. It simply becomes more evidently a vehicle to express man's inner life. If I have correctly interpreted the text referred to here, those who understand romantic art to be the death of art misunderstand Hegel's view. Romantic art is not the death of art; it is one more stage, and obviously is not the last stage in the history of art.

\section{C. "Poetry, alone among the arts, completely dispenses with the sensuous medium of the objective world of pbenomena." 33}

The third text is in reference to poetry. Its several variations, appearing throughout Hegel's long discussion of poetry, all suggest that 
poetry is the most successful of the arts in moulding bare sensuous form to the aims of subjectivity. Advocates of the death of art thesis attempt to use such passages to support their view. However, the strength of their argument diminishes when we examine the qualifications and limits that Hegel acknowledges, and when we apply the principle of dissolve to poetry.

Hegel identifies two principal ways in which poetry is superior to the other arts: in its representational powers and in its greater success at moulding sensuous form to the aims of subjectivity. (HA, 960, 966) Only the latter is important for the death of art thesis because superiority in representational powers does not suggest the dissolution of art. The references to the superiority of poetry are expressed negatively by Hegel and are overstated in order to contrast poetry with the other arts. However, for each statement emphasizing poetry's dispensing with the sensuous materials, there are important qualifications that are applicable to one or all. ${ }^{34}$ Hegel continues to remind us of the necessary qualifications leading to a correct sense of the negative overstatements.

A most important qualification arises from the necessity to communicate the results of the inner imaginative activity. Sensuous form remains essential for poetic communication as it does for the other arts. It is not seen as bare matter; instead it acts as a sign that is able to transmit the qualities of emotion and idea. The communication is possible because sensuous form is transformed and elevated through the activity of imagination.

A second qualification is with respect to changes in the natural materials of the different arts. When Hegel states that poetry will have nothing to do with gross matter as such, he is simply indicating the difference between the external materials of architecture and poetry. (HA, 960) In architecture the artist struggles with nature's raw materials of wood and stone. By the time art reaches the stage of poetry, its external "raw material" is language. Because language is already a product of mind, it requires less "working over" than do the materials of architecture. However, it remains that language is both thought and human speech or inscription, and poetry necessarily retains a sensuous form.

Hegel's understanding of the sensuous element in poetry can be seen clearly in examples of English romantic poetry. The English romantic theory of imagination, as it is discussed in nineteenth and twentieth 
century literary criticism, closely parallels Hegel's view. Analogous to Hegel's idea of dissolve, imagination acts in English romantic poetry to dissolve the oppositions of emotions and ideas to the sensory elements. Coleridge speaks of the "indissoluble union between the intellectual and the material world" in these words:

The Poet's heart and intellect should be combined, intimately ... and unified with the great appearances of nature, and not merely held in solution and loose mixture with them. ${ }^{35}$

The distinction between undissolved sensory material in art and the successfully dissolved can be seen in a contrast of sonnets with the same theme by William Lisle Bowles and Samuel Taylor Coleridge. ${ }^{36}$ The first is Bowles' "To The River Itchin."

Itchin, when I behold thy banks again,

Thy crumbling margin, and thy silver breast,

On which the self-same tints still seem to rest,

Why feels my heart the shiv'ring sense of pain?

Is it-that many a summer's day has past

Since, in life's morn, I carol'd on thy side?

Is it-that oft, since then my heart has sigh'd,

As Youth, and Hope's delusive gleams, flew fast?

Is it-that those, who circled on thy shore,

Companions of my youth, now meet no more?

Whate'er the cause, upon thy banks I bend

Sorrowing, yet feel such solace at my heart,

As at the meeting of some long-lost friend,

From whom, in happier hours, we wept to part.

The second is Coleridge's "To The River Otter."

Dear native Brook! wild Streamlet of the West!

How many various-fated years have past,

What happy and what mournful hours, since last

I skimmed the smooth thin stone along thy breast,

Numbering its light leaps! yet so deep imprest

Sink the sweet scenes of childhood, that mine eyes

I never shut amid the sunny ray,

But straight with all their tints thy waters rise,

Thy crossing plank, thy marge with willows grey,

And bedded sand that veined with various dyes

Gleamed through thy bright transparence! On my way,

Visions of Childhood! oft have ye beguiled

Lone manhood's cares, yet waking fondest sighs:

Ah! that once more I were a careless Child! 
Coleridge's poem is admittedly done in imitation of Bowles', and both deal with the theme of recollecting a childhood experience which is no longer vital. Yet, their differences exemplify an important distinction. Bowles simply sets up an associative relation between emotion and the sensuous elements of the poem. The sensuous is not integrally connected with the emotion. Compared to Bowles' poem, Coleridge's intensifies the color of sensibility with emotion and idea, giving a richness of significance that signals a fusion of ideas and emotions with sensuous material. ${ }^{37}$ The poet's imagination transforms the experience of nature into feeling or thought-infused lines, and brings them under the dominion of subjective spirit. Instead of the death of art, I find that the role of the sensory form is changed in accordance with the purposes of romantic art.

\section{Conclusion}

My conclusion is that Hegel did not intend the death of art. He uses the principle of dialectic to show the limits of art for communicating the highest religious truths of interest to man. The dialectic also shows the respective differences among the symbolic, classical, and romantic forms of art and gives a basis for comparing them according to their common use of sensuous and subjective elements. The sensuous and the subjective elements fall apart in romantic art only in a metaphorical way of speaking, and only to dissolve into a new image that makes the subjective element more prominent for this form of art. The texts that allegedly support the death of art thesis are less puzzling when the interpreter is mindful of their respective purposes of (1) justifying philosophy of art; (2) defining art's place and limits in relation to other modes of cognition; (3) contrasting and comparing the different forms of art. In effect, the aggregate force of the arguments offered here-the analysis of dialectic in Hegel's aesthetics, the examination of three principal texts, and the interpretation of dissolution in romantic art-recommends an interpretation that includes a future for art and warrants abandonment of the negative thesis of Croce, Heller, and Israel Knox. 


\section{NOTES}

1. Erich Heller, The Artist's Journey into the Interior (New York: Vintage Books, 1968), p. 115 .

2. Benedetto Croce, Aesthetic (tr. A. Maude) (New York: Noonday Press, 1958), p. $302 \mathrm{f}$.

3. Israel Knox, The Aesthetic Theories of Kant, Hegel and Schopenbauer (New York: Humanities Press, 1958), p. 103.

4. Bernard Bosanquet, "Appendix on Croce's Conception of the 'Death of Art' in Hegel," Proc. of the British Academy (1919), pp. 20-28.

5. M. Jacques D'Hondt, "La Mort de L'Art," a report in the Bulletin International D'Esthetique, 17 (June 1972), p. 4.

6. Karsten Harries, "Hegel on the Future of Art," Review of Metaphysics 27 (June 1974), pp. 677-96.

7. J. N. Findlay, Hegel: A Re-Examination (New York: Collier Books, 1962), pp. 341-46. Professor Findlay has expressed in private discussions with the author the opinion that Hegel could not have intended the death of art.

8. G. W. F. Hegel, The Philosophy of Fine Art (tr. Osmaston), (London: G. Bell \& Sons, 1920), pp. 139-44. The new translation of this work by Sir T. M. Knox did not appear until after this essay was presented, but page references to his edition are given in parentheses throughout the present text following the abbreviation HA. My citations to the German text are to Friedrich Bassenge's two volume edition (Berlin \& Weimar: AufbauVerlag, 1965). Hereafter I will give parallel references to those in the Knox translation by citing the Bassenge edition and the Osmaston translation in the following notes.

9. Israel Knox, op.cit., provides a representative statement. See p. 103.

10. Israel Knox's phrase is ambiguous here. The phrase "pass in review" can apply to either logical or metaphysical stages of the idea of Absolute Spirit, or to stages in art history.

11. Jean Hyppolite, Genesis and Structure of Hegel's Phenomenology of Spirit (tr. Cherniak and Heckman), (Evanston: Northwestern University Press, 1974), p. 64. See also pp. 65 and 597.

12. Osmaston translation, I, 381-83; Bassenge edition in the German, I, 275-76.

13. Osmaston, I, 139, 143; Bassenge, I, 108. See also Nathan Rotenstreich, "The Essential and the Epochal Aspects of Philosophy," Review of Metaphysics, 23 (1970), p. 714.

14. Rotenstreich, op. cit., p. 714. See Werke (Glockner), Vol. 19, p. 686.

15. Hegel differs from Schelling, who gives art the highest place in his System of Transcendental Idealism.

16. McTaggart notes in his discussion of the dialectic the inseparability of the dialectic in pure thought and in experience. It is inconceivable that Hegel would destroy art, the essential bridge between the two. J. M. E. McTaggart, Studies in the Hegelian Dialectic (Cambridge: Cambridge Univ. Press, 1896) Chapters $1 \& 2$.

17. Ibid., p. 1f.

18. Osmaston, III, 56; Bassenge, II, 46f.

19. Osmaston, III, 39; Bassenge, II, 33. 
20. Osmaston, III, 53-56; Bassenge, II, 44-47.

21. Osmaston, III, 127f; Bassenge, II, 99.

22. Osmaston, III, 130f; Bassenge, II, 101.

23. Osmaston, IV, 278f, 289; Bassenge, II, 535f, 543.

24. Osmaston, III, 224, Bassenge, II, 175.

25. This interpretation is in keeping with Hegel's general philosophical practice of regarding nature as a lower form of reality in need of being transformed by the activity of mind. Nature acquires greater importance for Hegel when it is allied with mind's purposes. By analogy, so should the sensuous in art. Below, I will seek to show that the sensuous in romantic art must retain a positive role.

26. "In allen diesen Beziehungen ist und bleibt die Kunst nach der Seite ihrer höchsten Bestimmung für uns ein Vergangenes." (Bassenge, I, 22; Osmaston, I, 13).

27. J. Glenn Gray, G. W. F. Hegel on Art, Religion, Pbilosophy (New York: Harper Torchbooks, 1970), p. 18.

28. Osmaston, I, 11f; Bassenge, I, $21 \mathrm{f}$.

29. This point was suggested to me by an anonymous critic of an earlier version of the essay.

30. "Dadurch erhalten wir als Endpunkt des Romantischen überhaupt die Zufälligkeit des Äusseren wie des Inneren und ein Auseinanderfallen dieser Seiten, durch welches die Kunst selbst sich aufhebt und die Notwendigkeit für das Bewusstsein ziegt . . ."Knox translates this text as follows: "Therefore we acquire as the culmination of the romantic in general the contingency of both outer and inner, and the separation of these two sides, whereby art annuls itself and brings home to our minds that we must acquire higher forms for the apprehension of truth than those which art is in a position to supply." (529) Cf. Bassenge, I, 509; Osmaston, II, 296.

31. Random House Dictionary of the English Language (Unabridged edition, 1967), p. 416.

32. The St. Louis Art Museum contains the original works cited here.

33. "Unter allen Künsten entbehrt nur die Poesia der vollen, auch sinnlichen Realität ausserer Erscheinung." Knox translates this: "Of all the arts poetry alone does not appear outwardly in something completely real and also perceptible" [sic]. (1181), Bassenge, II, 535; Osmaston, IV, 278. Variations of the statement are found on HA, 960 and 966 (Osmaston, II, 328, 334; Bassenge, II, 960, 966).

34. See 964-66, 977-78, 1181 (Osmaston, IV, 10-13, 27-29, 278; Bassenge, II, 331-34, $343-45,535)$.

35. S. T. Coleridge, Letters (Boston, 1895), Vol. I, p. 404. Cited in William K. Wimsatt, Jr., The Verbal Icon: Studies in the Meaning of Poetry (New York: Noonday Press, 1958), p. 107.

36. I am indebted to Wimsatt's essay "Romantic Nature Imagery" for this example. In Wimsatt, op.cit., pp. 105-10.

37. Ibid., pp. 106-09, 115. 